(mild or confluent), dermal vaccinia, neurovaccinia, or generalised vaccinia of the rabbit. Out of 195 tests on human material only three (cases of variola minor) gave apparently erroneous results : all crusts from cases of chickenpox were negative. The test is therefore specific and indicates the identity of the infecting virus of smallpox with that of vaccinia (or cowpox, the attenuated virus which is used to develop immunity to smallpox in human beings by 'vaccination'). These results also show that the secondarily infecting bacteria present in dermal material have no influence on the reaction; this conclusion was confirmed by further direct experiments. Thus it was found that crust extracts removed the flocculating property from antivaccinia serum, but failed to remove the staphylococcal agglutinating bodies from antistaphylococcal serum; and that absorption with suspensions of secondarily infecting bacteria had no effect on the flocculating properties of anti-vaccinia serum although such absorption rendered inert the antisera specific to the secondarily infecting organisms.

An antiserum such as is used for the flocculation test appears to exert a specific antibody action on the virus in vitro. After four hours incubation at $37^{\circ} \mathrm{C}$. of a mixture of serum and virus the latter is inactivated or destroyed, since no lesion is produced on dermal inoculation: destruction is theoretically unlikely and probably does not actually occur since infection may be produced if inoculation is made into the rabbit's testes.
On the other hand, evidence was obtained that passive immunity to vaccinia could be produced in rabbits and guinea-pigs by the injection of antivaccinia serum possessing flocculating properties. The immunity of the animals was tested by dermal, testicular, and intravenous inoculation of virus: the results did not depend on the serum or strain of virus used.

As a natural sequel to the above results, attempts were made to produce immunity by the use of virus sensitised with antiserum. It was found that such a mixture, although failing to 'take' on dermal inoculation, produced, on subcutaneous injection into rabbits, a very high degree of immunity. The importance of this observation lies in the fact that it may be possible to produce immunity in human beings by this method without the risk, small though it is, of the development of the sequelæ, such as vaccinal encephalitis, which occasionally follow ordinary 'vaccination'. The theoretical objection to the use of sensitised virus is that although the antiserum may control the infection at the site of injection, it may be powerless to do so if the virus is disseminated: the authors are carrying out further investigations on this point. In any event, the results of the experiments on the production of passive immunity suggest that it might be possible to immunise smallpox contacts so that the disease would be aborted even in circumstances when vaccination might fail to prevent infection.

\title{
Obituary
}

Mr. Louts Brennan, C.B.

$\mathrm{B}^{\mathrm{Y}}$ $Y$ the death of Louis Brennan on Jan. 17, at Montreux, Switzerland, Great Britain loses an inventor whose name was once very widely known. Born at Castlebar, Ireland, on Jan. 28, 1852, Brennan at an early age went to Australia, and it was while working as a watchmaker in Melbourne that he conceived the idea for a torpedo which could be fired and controlled from a fixed position.

Assisted by a member of the staff of the University of Melbourne, towards the end of the seventies of last century Brennan succeeded in arousing the interest of Government officials, and in 1880 the Admiralty appointed a committee of naval officers serving on the Australian station to report on the torpedo. Their report being favourable, Brennan was brought to England, and as the torpedo was considered very suitable for the defence of creeks and harbours, the matter was taken up by the War Office, Brennan being attached to the Royal Engineers at Chatham, and a torpedo factory being built at Gillingham. Brennan was at first given a retaining fee of $\mathfrak{£ 5 0 0 0}$ and a salary of $\mathfrak{£ 2 0 0 0}$. He superintended the factory for many years, and from 1896 until 1907 was retained as consulting engineer.

Like Whitehead's automobile torpedo, Brennan's machine was fish-shaped and had fins, horizontal and vertical rudders, hydrostatic depth control, and double propellers, but it was driven and con- trolled by two wires running over drums driven by a steam engine in the firing station and connected with other drums in the body of the torpedo.

At Gillingham, Brennan began his work on the monorail locomotive with gyroscopic stabilisers. His model, now in the Science Museum, South Kensington, was described in the technical press in 1907, and a public trial of his car took place at Gillingham on Nov. 10, 1909. The car was $40 \mathrm{ft}$. long, $10 \mathrm{ft}$. wide, and $13 \mathrm{ft}$. high, and had a wheel base of $20 \mathrm{ft}$. and a weight of 20 tons. It ran on a single rail track, which included a circular path 200 yards round, and successfully carried a party of 40 persons. It was fitted with two petrol engines driving electric generators supplying current to the driving motors, and to two large gyroscopes which preserved the balance of the car in all circumstances. Each gyroscope had a wheel weighing three-quarters of a ton, revolving at 3000 r.p.m. in a casing from which the air was exhausted. On the day of trial, owing to one of the generators being out of action, a speed of only 7 miles an hour was attained, but the designed full speed was 35 miles an hour. Brennan himself envisaged a monorail car $150 \mathrm{ft}$. long and $25 \mathrm{ft}$. wide travelling at about twice the speed of existing railway trains, but his invention did not lead to any development.

During the War, Brennan served with the Ministry of Munitions and later with the Air Ministry, and 
experimented with a helicopter, but much of his work was of a confidential nature. He received the honour of C.B. in 1892, in 1906 was made a honorary member of the Royal Engineers' Institute, and in 1922 a foundation member of the National Academy of Ireland.

\section{Mr. C. J. Merfield}

The tragic death of Mr. Merfield as the result of a motor accident occurred on Jan. 23, 1931, but it did not become known in England intil later. He was a very zealous and active worker, and undertook a large number of extensive astronomical computations. In his early career he was a surveying engineer, but even then he computed the orbits of comets in his spare time; the orbits of comets 1897 I, 1901 I, etc., were published in Astronomische Nachrichten. The last was a very bright southern comet; Mr. Merfield's elements, which indicate a period of 39,000 years, are accepted as definitive.

A few years later, Mr. Merfield joined the staff of the Sydney Observatory; he moved to Melbourne Observatory in 1908, and became chief assistant there in 1919, a position which he held until his death. He continued his work on comets, deducing an accurate orbit of Halley's comet from the early observations, and tracing the perturbations of the Pons-Winnecke comet for a long period, including its near approach to the earth in 1927. In his earlier years he had studied under Dr. R. T. A. Innes; it was doubtless at the suggestion of the latter that he performed the laborious task of computing the secular perturbations of Eros, Ceres, and Iris ; these were published in Astronomische Nachrichten in 1907 and 1909.

Mr. Merfield was also interested in eclipses, and computed their circumstances in Australia and the neighbourhood; he observed the total solar eclipses of 1901, 1910, and 1911. His son, Mr.
Z. A. Merfield, is the Australian representative on the Solar Eclipse Committee of the International Astronomical Union. We are indebted for many of the above details to Mr. J. A. Moroney, president of the Astronomical Society of Victoria, of which Mr. Merfield was the first president on its formation in 1922 .

Prof. Holland Crompton, formerly professor of organic chemistry at Bedford College, London, who died on Dec. 22, 1931, was born in Preston, Lancashire, on April 30, 1866 . He attended school in Stuttgart and later studied chemistry under Prof. H. E. Armstrong at the City and Guilds Institute. In 1888 he was appointed lecturer and head of the Department of Chemistry at Bedford College, London, in succession to Spencer U. Pickering. He held this post until 1919, when the department was divided, and from that date until his retirement in 1927, on account of ill-health, he was head of the Department of Organic Chemistry. Crompton never enjoyed robust health, and in his later years it became steadily worse. He will be remembered by both organic and physical chemists on account of his work on acenaphthene, atomic energy and the specific heat of gases, molecular association and molecular magnitudes, osmotic pressure and the electrolytic dissociation theory.

\section{We regret to announce the following deaths:}

Prof. Clarence L. E. Moore, professor of mathematics in the Massachusetts Institute of Technology, Cambridge, Mass., who devoted particular attention to the geometry of the sphere and circle in space, on Dec. 5, aged fifty-five years.

Prof. R. Stenhouse Williams, first director of the National Institute for Research in Dairying, Shinfield, Reading, and research professor in dairy bacteriology in the University of Reading, on Feb. 2, aged sixty years.

\section{News and Views}

\section{Determinism Defined}

Sir Arthur Edoington's characteristically fascinating address on "The Decline of Determinism", which we publish as our Supplement this week, will be welcomed as a clear, unequivocal statement, by a leading authority, on a question which, even among the many revolutionary aspects of the new physics, holds a pre-eminent place for importance and interest. Such a statement is the more necessary because of the almost universal tendency for discussions of determinism to be concerned at bottom with words rather than ideas, and Sir Arthur has quite properly begun by stating definitely what he means by the determinism which he holds has declined. His thorough analysis leaves little room for disagreement, but many will wonder whether he has not achieved a Pyrrhic victory by conceding to the determinist the substance of his doctrine and destroying only the shadow. "The rejection of determinism is in no sense an abdication of scientific method", and "indeter- ministic or secondary law . . . can be used for predict. ing the future as satisfactorily as primary law". In other words, Sir Arthur does not allow that the first Morning of Creation wrote what the last Dawn of Reckoning shall read, but he allows that it might have read what the last Dawn shall write. Even the most perfervid determinist will scarcely ask more. Furthermore, he acknowledges that he does not know whether Dirac, whose book "goes as deeply as anyone has yet penetrated into the fundamental structure of the physical universe", is a determinist or not. It would seem, therefore, that the determinism in question cannot be of much importance even in physics.

\section{Physical Inference and Prediction}

Apparentry, however, in spite of the unqualified statement concerning prediction quoted above, Sir Arthur denies that we can predict the behaviour of electrons more certainly than that of horses, and the importance, to all but the physicist, of the "decline

$$
\text { No. 3250, VoL. 129] }
$$

